\title{
Preface
}

\section{On the origin of Darwinism}

Charles Darwin was almost scooped. A quintessential thinker, after five years voyaging around the globe on the HMS Beagle and filling notebooks upon notebooks with his careful observations, he did not rush to widely disseminate the conclusions of his field study. Almost 20 years passed during which he further reflected on what he called "his theory" before he was urged to publish simultaneously with Alfred Russell Wallace, another naturalist and great thinker, who had independently formulated similar conclusions on variation within species and survival of the fittest (Darwin and Wallace 1858). These first extracts from Darwin's memoir were short and merely outlined what Darwin termed "natural selection," but they established that he was the father of what we now know to be one of the greatest conceptual contributions to science and society.

Two-thousand-and-nine marks the 200th year since Charles Darwin's birth and the 150th anniversary of the initial publication of On the Origin of the Species, inspiring many celebrations of his life and reviews of the history of evolutionary biology, which stemmed from his cogitations (Darwin 1859). Genome Research is also commemorating the occasion, as it is precisely the time to take stock of the vast progress the fields of genetics and genomics have made in evolutionary biology since the seeds of Darwinism were sowed. Synthesis with the laws of heredity, population genetics, and the advances in DNA sequencing prompt us to devote this special issue to both primary research and reviews in comparative genomics, genome evolution, and population genomics, all occasioned by Darwin's seminal discoveries.

This issue begins with discourse from the renowned evolutionary geneticist and philosopher, Francisco Ayala, on the history of the question posed by "design" in nature-the beautiful, the slapdash, and often-bizarre complexity of organisms (Ayala 2009). Ayala recounts the story of Darwin's revolutionary explanation and the world's response. Perspective reviews from other leading biologists follow and provide critical insight into how genomics has contributed to a contemporary molecular understanding of Darwin's discoveries. Kenneth Weiss and Jeffrey Long warn of the inferences made regarding human variation by admixture-based analyses of global samples and the interpretation of increasingly popular "recreational" genetic ancestry analysis (Weiss and Long 2009). Joshua Akey (2009) integrates the lessons learned from recent genome-wide scans of positive selection in humans, and points the way to detailed characterization of adaptive alleles via deeper candidate gene studies, systems biology, an extension of the modern synthesis beyond the inclusion of theoretical population genetics and Mendelian principles (Huxley 1942) to epigenetic inheritance, for example, and by applying whole genome sequence data now at our fingertips.

In other reviews, Jonathan Flint and Trudy Mackay compare the genetic architecture of quantitative traits in different species: flies, rodents, and humans (Flint and Mackay 2009). They highlight the contributions of epistasis, pleiotropy, gene-environment interactions and variants in noncoding regions, and offer guidance to advancing our understanding of the molecular basis of quantitative traits. Chung-I Wu and colleagues offer a hypothesis on the evolutionary role of microRNAs as "shock absorbers," stabilizing phenotypes by buffering gene expression (Wu et al. 2009), and W. Ford Doolittle and Olga Zhaxybayeva take a Darwinist view in demonstrating there's no universally applicable prokaryotic "species" concept, but argue that, in the absence of species definitions, progress in metagenomics will surely guide us toward a deeper understanding of evolution in these populations (Doolittle and Zhaxybayeva 2009). These reviews emphasize the advances in our understanding of evolutionary concepts made possible by progress in genomic research, outline the current challenges we face, and offer likely paths ahead over the next few years.

Primary research reports in this special issue all reflect Darwinian themes. They include detailed analyses of fine-scale population structure, human genetic variation, and recent positive selection acting on genes associated with complex disease, the evolution of specific gene families in humans and non-human primates, characterization of the evolutionary changes in mammalian genome organization, selection acting upon duplicate genes, Alu repeat phylogeny, the evolution of a human centromere and of alternative splicing, transcriptome evolution, and novel tools for reliable ancestral genome reconstruction. The research considers species from humans to plants to parasitic lice, whose highly fragmented mitochondrial DNA structure may have coevolved with blood feeding (Rand 2009; Shao et al. 2009).

This issue celebrates Darwinism - a term originally coined by T.H. Huxley (1860) and later used by other advocates of Darwinian principles, including by his grandson Julian Huxley (1992). It may seem that Darwinism is an inappropriate term to promote, as it is not common in scientific literature and currently is used pejoratively by creationists. It is true that there are fewer scientific -isms in general (fewer than political, religious, or philosophical -isms [Reaganism, Machiavellianism, Buddhism]), but if Mendelism describes Mendelian inheritance, then why not Darwin's eponymous principles? Its intended use here is not to ignore how much more complicated evolutionary biology is now, extending well beyond Darwin's imagination, nor is it meant to devalue all the great thinkers since Darwin. ${ }^{1}$ In fact, it is the perfect time to reclaim the term, resurrecting it into proper use, rid it of its derogatory connotation (much like the word "Gothic" has been transformed from something ugly to revered). Let us hold Darwinism high as an historical tribute to Darwin himself and give credit where credit is due. We give the term credence here to celebrate a great thinker, whose keen observations and revolutionary synthesis of testable hypotheses laid the foundation for all that has become of evolutionary biology.

Darwinism is not only about the musings of a naturalist. Darwinism is about the man behind the principles of natural selection and "common descent with modification," who still casts a guiding light for the great thinkers of today.

This leads us to the last paper Darwin published, without the hesitation that characterized his premier work. The story behind it goes, as recounted by David Quammen (2006), that one day late in his life, Darwin received a letter from a shoe salesman, named Walter Crick, who, out on a trek in the woods, noticed a water beetle with a tiny freshwater clam attached to one of the legs, and, thinking it curious, he mailed it to Darwin. Darwin at once noted the possibilities of dispersal exemplified by "flying clams" and after euthanizing the poor specimen on a bed of laurel leaves, and 
only shortly before passing away himself, he wrote his last paper (Darwin 1882). A great thinker indeed-and the shoe salesman's grandson, Francis Crick, turned out to be a thought leader in his own right. .

Hillary E. Sussman, for the Editors of Genome Research

\section{References}

Akey, J.M. 2009. Constructing genomic maps of positive selection in humans: Where do we go from here? Genome Res. (this issue). doi: 10.1101/gr.086652.108.

Ayala, F.J. 2009. One hundred fifty years without Darwin are enough! Genome Res. (this issue). doi: 10.1101/gr.084285.108.

Darwin, C. 1859. On the origin of species by means of natural selection, or the preservation of favoured races in the struggle for life, 1st ed. John Murray, London, UK.

Darwin, C. 1882 . On the dispersal of freshwater bivalves. Nature 25: 529-530.

Darwin, C. and Wallace, A.R. 1858. On the tendency of species to form varieties; and on the perpetuation of varieties and species by natura means of selection (Read July 1, 1858.) J. of the Proc. of the Linnean Soc. of London. Zoology 3: 45-62.
Doolittle, W.F. and Zhaxybayeva, O. 2009. On the origin of prokaryotic species. Genome Res. (this issue). doi: 10.1101/gr.086645.108.

Flint, J. and Mackay, T.F.C. 2009. Genetic architecture of quantitative traits in mice, flies, and humans. Genome Res. (this issue). doi: 10.1101/ gr.086660.108.

Huxley, J.S. 1942. Evolution: The modern synthesis. Allen and Unwin, London, UK.

Huxley, J.S. 1992. Evolutionary humanism. Prometheus, Buffalo, NY.

Huxley, T.H. 1860. [Review of] On the origin of species, pp. 541-570. Westminster Review 17 (n.s.), UK.

Quammen, D. 2006. The reluctant Mr. Darwin: An intimate portrait of Charles Darwin and the making of his theory of evolution. Great discoveries. Atlas Books/Norton, New York.

Rand, D. 2009. 'Why genomes in pieces?' revisited: Sucking lice do their own thing in mtDNA circle game. Genome Res. (this issue). doi: 10.1101/ gr.091132.109.

Shao, R., Kirkness, E.F., and Barker, S.C. 2009. The single mitochondrial chromosome typical of animals has evolved into 18 minichromosomes in the human body louse, Pediculus humanus. Genome Res. (this issue). doi: $10.1101 /$ gr.083188.108

Weiss, K.M. and Long, J.C. 2009. Non-Darwinian estimation: My ancestors, my genes' ancestors. Genome Res. (this issue). doi: 10.1101/ gr.076539.108.

Wu, C.-I, Shen, Y., and Tang, T. 2009. Evolution under canalization and the dual roles of microRNAs-A hypothesis. Genome Res. (this issue). doi: 10.1101/gr.084640.108. 


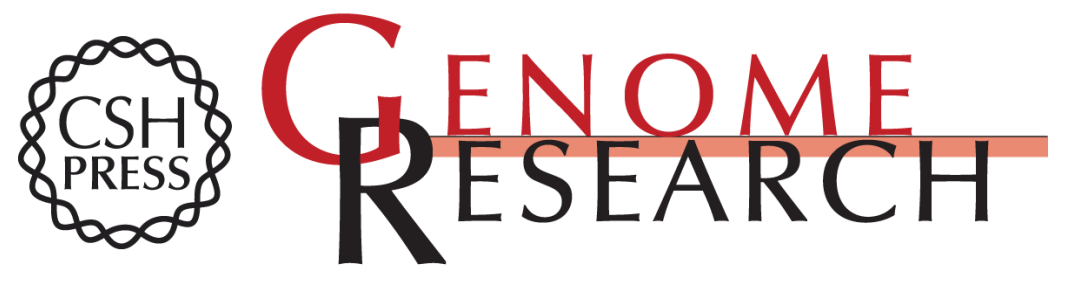

\section{On the origin of Darwinism}

Hillary E. Sussman

Genome Res. 2009 19: 691-692

Access the most recent version at doi:10.1101/gr.094458.109

\section{License}

Email Alerting Receive free email alerts when new articles cite this article - sign up in the box at the Service top right corner of the article or click here.

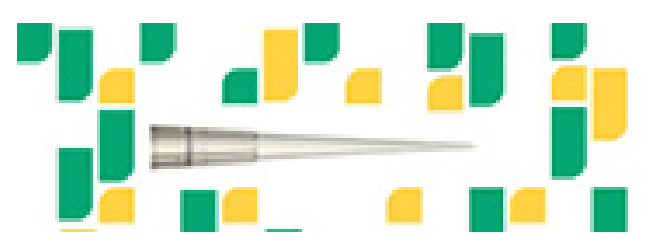

To subscribe to Genome Research go to: https://genome.cshlp.org/subscriptions 